\title{
ENKELE AANTEKENINGE BY DIE TEOLOGIES-GODSDIENSTIGE GEDAGTES VAN SENDELING S. J. G. HOFMEYR \\ 1839-1905
}

Een van die bekendste en tewens die eerste Afrikaanse sendeling van die Kaapse Nederduits Gereformeerde Kerk in die ou Zuid-Afrikaanse Republiek was Stephanus Johannes Gerhardus Hofmeyr wat vanaf Februarie 1865 tot aan sy dood in 1905 in die Soutpanshergse wêreld sendingwerk gedoen het ${ }^{1}$. Hofmeyr is op 3 Junie 1839 in Kaapstad gebore as die agste kind van sy vader Jan Hendrik Hofmeyr, wat destyds advokaat aan die Kaapse balie was, en sy moeder Anna Martina Neethling². Sy moeder veral het daarvoor gesorg dat die jong Stephanus 'n streng godsdienstige opvoeding ontvang het. Van sy vroegste dae af word hom die erns van die daad-sonde op die hart gedruk en word hom voorgehou dat hy na 'n Gode-welgevallige lewenswandel moet streef. Uit die beskikbare gegewens kan gekonkludeer word dat sy godsdienstige opvoeding sterk piëtisties van aard was. Sodoende is die fondament vir Hofmeyr se latere teologies-godsdienstige insigte reeds hier in sy ouerhuis gelê. ${ }^{3}$. Sy eerste jare bring Hofmeyr in Kaapstad deur tot in 1849 wanneer die familie weens finansiële redes na Soutrivier trek. Dit beteken ook 'n tydelike onderbreking van sy formele skoolopleiding ${ }^{4}$ omdat hy nou moes help om die finansiële laste van die familie te dra. 'n Gedeeltelike hoërskoolopleiding kan die jong Hofmeyr egter tog aan die engelstalige South African College in Kaapstad ontvang ${ }^{5}$. Maar ook hierdie opleiding duur nie lank nie, want as sy vader in 1855 as magistraat te Bredasdorp aangestel word, moet die 16-jarige Hofmeyr die College verlaat om „klerk en agent” by sy vader te word. Voordat hy egter uit Kaapstad vertrek, word hy nog, op verlange van sy vader, belydende lidmaat van die Ned. Gereformeerde Kerk. Besondere waarde het Hofmeyr nie aan hierdie gebeurtenis geheg nie $^{6}$ :

Ik had bijbelkennis genoeg om de vragen te beantwoorden, doch ik voelde mij een onbekwaam en onwaardig lidmaat, daar ik wist dat ik onbekeerd was.

Die jong Hofmeyr was egter van rustelose aard. As dit blyk dat hy in

\footnotetext{
${ }^{1}$ Stêfanus Hofmeyr, Twintig Jaren in Zoutpansberg. Een verhaal van twintig Jaren arbeid onder de Heidenen in de Transuaal, Kaapstad 1890, bls. 1. Dit is in 1857 dat die Kaapse Ned. Gereformeerde Kerk op sy Sinode in besluit t.o.v. die „Buitenlandsche Zending" geneem het.

2 M.N., Het Leven van Stephanus Hofmeyr, Wellington 1907, blz. 1. Vgl. C. C. de Villiers, Geslacht-register der Oude Kaapsche Familiēn, Kaapstad 1893, Dl. I, blz. 344.

${ }^{3}$ M.N., a.w., blz. $1-3$.

- M.N., a.w., blz. 3. Hofmeyr se ouer susters het hom nog onderwys gegee sodat sy ontwikkeling nie heeltemal stopgesit is nie.

5 M.N., a.w., blz. 3. As sy leermeesters alhier word Drr. Adamson, Dale, Heyns, Evelyn, Eerw. Smalley en Childe genoem.

- M.N., a.w., blz. 4.
} 
Bredasdorp nie deug nie, vind hy werk by 'n afslaer in Kaapstad. Maar ook daar wil dit nie vlot nie. Later sê hy van sy jeugjare ${ }^{\top}$ :

Te Bredasdorp werd ik van wild en stout, bepaald slecht. $O$, die jaren aldaar! Ik was een voorpaard van den Duivel, en bewandelde den breeden weg des verderfs met alle mijne krachten. De Heer die mij van eeuwigheid uitrerkoren had, alhoewel ik Hem niet kende, liet mij niet toe iedere zonde te doen, doch uitgenomen moord heb ik iedere zonde willen doen; zoo dat ik eindelijk zelfs ook aan zelfmoord dacht. Teen die einde van 1858 gaan Hofmeyr na 'n oom van hom wat op die plaas Remhoogte naby Meiringspoort geboer het. Hier in 'n rustiger atmosfeer vind Hofmeyr 'n sekere ewewigtigheid. Onder invloed van sy oom en neef, deur die lees van opwekkende artikels in De Kerkbode en De Wekker, asook deur drome, hegin Hofmeyr nou 'n meer christelike lewenswandel te voer ${ }^{8}$.

'n Sekere onstabiele trek in Hofmeyr se karakter word reeds hier al duidelik - hy is 'n man van uiterstes want hy is of ' $n$ volslae lewensgenieter sonder rem of verantwoordelikheid, of 'n toegewyde christen in die aktiwisties-piëtistiese patroon ${ }^{9}$. Dit was dus te begrype dat toe die opwekkings-beweging, wat in 1859 ook in die Ned. Gereformeerde Kerk aan die Kaap geïntroduseer is, na die Prins Albert distrik uitgebrei het, Hofmeyr die besondere byeenkomste en bidure gaan bywoon het ${ }^{10}$. Dit het in die eerste plek ' $n$ sterk neiging tot askese by hom laat posvat ${ }^{11}$ asook 'n uitgesproke behoefte na die wedergeboorte. Om die ervaring van die wedergeboorte te kan bereik, wat hy as 'n sine qua non vir hom-

7 M.N., a.w.. blz. 4. Dit mag hier in gedagre gehou word dat hierdie tipering van sy jeugjare in latere tyd te boek gestel is. Dit lê natuurlik heeltemal in die metodistiese gedagte-patroon om die pre-bekeringsperiode in die lewe so swart moontlik te skilder om so die ommekeer en (byna) sondelose lewe, wat volgens die metodisme, op die ware bekering volg, duideliker te aksentueer. Hofmeyr se biograaf stel hierdie gedagte ook. Vergelyk M.N., a.w., blz. 1.

${ }^{8}$ M.N., a.w., bl=. 5: Een droom, waarin ik den ouden Heer Kootje de Wet van de Kaapstad zag, die liet zingen Gez. 158:4, en een stukje dat ik . . las, onder het hoofd: Zijt gij ? (wedergeboren) ... alle die dingen en nog meer brachten mij tot mijselven.

'M.N., a.w., blz. 5 .

10 Oor die ontstaan en inhoud van die opwekkingsbeweging aan die Kaap, kan verwys word na die opmerkings van S. P. Engelbrecht, Thomas Francois Burgers. 'n Lewenskets, Pretoria-Kaapstad 1933, bls. 41-43; A. C. Barnard, Die Pinksterfees in die Kerklike Jaar, Kampen 1954, bls. 138 vg., en ook T. N. Hanekom, Ons Pinksterbidure, hoe het hierdie gebruik ontstaan? artikel in Die Kerkbode, 22 April 1953, bls. $322 \mathrm{vg.} \mathrm{In} \mathrm{kort}$ kom dit daarop neer dat hierdie opwekkingsbeweging wat in die jaar 1857 in Amerika ontstaan het en vandaar ook na ander lande uitgebrei het, ook in Suid Afrika deur die kerklike leiers geintroduseer is. Daar is gemeen dat hierdie amerikaans-engelse godsdienstige beweging die toenemende invloed van die liberalisme in die Kaapse Ned. Gereformeerde Kerk sou kon stuit. In Augustus 1859 het die Zuid-Afrikaansch Evangelisch Verbond aan alle Evangeliedienare van alle kerke in Suid-Afrika 'n skrywe gerig om ook die opwekking hier tot stand te bring. Dit het tot gevolg gehad dat 'n kragtige herlewing omstreeks Mei 1860 op die dorp Montagu plaasgevind het vanwaar dit spoedig na ander gemeentes van die Ned. Gereformeerde Kerk uitgebrei het. In 1862 het die Sinode van die Ned. Gereformeerde Kerk hierdie opwekking offisieel gesanksioneer en dir as 'n besondere werk van die Heilige Gees aanvaar. Vlg. Handelingen der Tiende Vergadering van de Synode der Gereformeerde Kerk c'an Zuid-Afrika, Kaapstad 1863, Dl. I, blz. 49-50.

${ }^{11}$ M.N., a.w., blz. 5: (ik) ging veel om met den Bijbel, bad veel, lachte soms volstrekt niet, wilde soms over niets dan over geestelijke dingen spreken. 
self gestel het ${ }^{12}$, het Hofmeyr wat 'n soort van oefenaar en voorganger by godsdienstige byeenkomste in die distrik was $^{13}$, sy godsdienstgie werksaamhede met nog groter ywer voortgesit en terselfdertyd homself aan 'n voortdurende, noulettende selfondersoek onderwerp, weinig geslaap, en sy hele gedagtewêreld gekonsentreer om die ideaal van die wedergeboorte te bereik ${ }^{14}$. In die vroeë môre van 24 Maart 1862, nadat hy en sy neef die nag deurgebring het om brandewyn te stook, het dit gebeur ${ }^{15}$ :

Toen de emmers vol was, nam ik dien en ging naar het vat om de brandewijn daarin te werpen... I $k$ voelde mij zoo ellendig, stond met mijn hoofd voorover en eene hand op mijn hart, want het was ,, hartpijn”. Terwijl ik zoo stond, zeide ik: „Ach Heer, wat zal ik doen, ik heb alles geprobeerd en niets helpt, ik kan niet meer bidden of weenen, krijg toch voor mij jammer". Op dat oogenblik, bliksemsnel was het alsof de hemel en mijn hart tegelijk opensprongen. En gloed van liefde verwarmde mijn ziel ... O welk eene liefde gevoelde ik tor den Heiland.

Sy bekering en wedergeboorte was vir Hofmeyr van so 'n sentrale betekenis dat hy in later tyd nog tweemaal die plek gaan besoek ,waar ik de Heere Jesus leerde kennen en liefhebben"16. Na sy bekering het Hofmeyr voortgegaan met sy godsdienstige werk en dit ook uitgebrei deur evangeliserende werk onder die werkvolk op die plaas te doen ${ }^{17}$.

Terwijl ik zoo voor den Heere, die mij gered had, iets trachtte te doen, kwam bij mij de begeerte op, als Zendeling ver onder de Heidenen te gaan arbeiden;

Hoewel Hofmeyr in die begin nié aan hierdie innerklike drang wil gehoor gee nie, word hy deur 'n siekte en deur 'n brief van Ds. J. H. Neethling, destydse sekretaris van die Sendingkommissie van die Kerk, oortuig dat dit tog sy roeping is om as sendeling onder die "woeste heidenen" te gaan arbei ${ }^{18}$. Om hierdie ideaal te bereik vertrek Hofmeyr in 1862 na Stellenbosch om hom as sendeling te bekwaam. Hoewel hy oorreed word om die normale teologiese opleiding wat van die predikante vereis is, te volg, blyk spoedig dat sy voorafgaande skoolopleiding te gebrekkig was om dit te kan bereik ${ }^{19}$. Nadat hy homself oorwerk het, laat hy die teo-

\footnotetext{
12 M.N., a.w., blz. 5: Ik moet wedergeboren worden, zoo niet ik zal maar weer terugvallen naar de wereld; $i k$ zal het in den hemel niet kunnen uithouden.

${ }^{13}$ M.N., a.w., blz. 5-6.

${ }^{14}$ M.N., a.w., blz. 6-7.

15 M.N., a.w., blz. 7.

$16 \mathrm{~S}$. Hofmeyr, a.w., blz. 31 en 48.

17 S. Hofmeyr, a.w., blz. 29. 'n Groot ywer vir die sending het feitlik hand aan hand met die opwekkingsbeweging gegaan en het sodoende 'n groot stoot aan die sendingaksie van die Kaapse Ned. Gereformeerde Kerk gegee. Vlg. J. du Plessis, Het Leven van Andrew Murray, Kaapstad 1920, blz. 207 v.

18 S. Hofmeyr, a.w., blz. 29.

10 M.N., a.w., blz. 8: Mijn verlangen was zendeling te worden; langs den kortst mogelijken weg, dat is, eerst godsdienst-onderwijzer, en dan zendeling, en dan geordend doch men wilde dat ik mij eerst moest klaarmaken voor het admissie-examen van de Theologische kweekschool, en dan door de Kweekschool naar de Heidenen.
} 
logiese studie vaar en lê in 1863 die godsdiensonderwysers-eksamen af met die bedoeling om dan later die sendelingseksamen af te $l^{20}$.

Hofmeyr kry nou 'n werkkring onder die kleurlinge te Franschhoek en is terselfdertyd ook in die blanke gemeente behulpsaam. Dit bevredig hom egter nie want hy wil in die vreemde gaan sendingwerk doen ${ }^{21}$. Teen die einde van 1864 word Hofmeyr dan vanuit die kerkgebou te Stellenbosch afgevaardig na Noord-Transvaal. Dit was vir die Ned. Gereformeerde Kerk 'n groot oomblik want Hofmeyr was die eerste Afrikaner wat deur dié kerk na die sendingveld gestuur is. Verskillende vooraanstaande kerkleiers was dan ook aanwesig, naamlik ds. J. H. Neethling, ds. Andrew Murray, ds. Charles. Murray en Prof. N. J. Hofmeyr. Van dió plegtigheid word vermeld ${ }^{22}$ :

Ds. C. Murray, destyds Zending-Inspector, sprak een ernstig woord:

Om het werk, dat de Heer Jesus onvoltooid had gelaten, op zijn bevel, naar zijn voorbeeld te mogen voortzetten, was niet een woord over het bevel van Christus-,Gaat henen in de geheele wêreld, predikt het Evangelie aan alle creaturen". Welk een zaligheid, het te mogen gehoorzamen. Hij beval zich aan in de gebeden der geloovigen.

In 1865 begin Hofmeyr sy werksaamhede as sendeling as hulp van sendeling A. McKidd wat die sendingstasie Goedgedacht teen die Soutpansberge in Noord-Transvaal aangelê het ${ }^{23}$. Hofmeyr se werksaamhede was hoofsaaklik ten behoewe van die groep gekleurde Buys-nakomelinge aldaar en die omwonende naturellestamme ${ }^{24}$. Vroeg in 1865 egter het McKidd aan geelkoors gesterwe sodat Hofmeyr alleen die werk moes voortsit waarvoor hy 'n minimum van opleiding maar wél 'n groot ywer gehad het. Omdat hy as ongeordende nie die sakramente kon bedien nie, moes Hofmeyr wel na die Kaap terugkeer om as sendeling georden te word. Daarvoor het hy in 1866 na die Kaap teruggekeer, daar die sendelingseksamen afgelê terwyl hy in dieselfde tyd met Anna Neethling,

${ }^{20} \mathrm{~S}$. Hofmeyr, a.w., blz. 30: Mijne vrienden overtuigd dat mijn hoofd mij nooit in de kweekschool brengen zou, stemde toe dat ik zou opgaan voor't Godsdienst Onderwijzersexamen, dat ik in 1863 passeerde.

${ }^{21}$ M.N., a.w., blz. 9-14.

22 M.N., a.qv., blz. 16.

${ }^{23}$ Oor sendeling McKidd vergelyk: A. Dreyer, Kruisgesante in Suid-Afrika. Jubileum Gedenkboek van die sendinginstituut op W'ellington 1977-1927, Kaapstad 1927, blz. 49.

24 Vgl. S. Hofmeyr, a.4., blz. 6-15. Oor die geskiedenis van Coenraad Buys, die stamvader van hierdie groep, vgl. S. G. Millin, King of the Bastards, London s.j. Vgl. ook: A. E. Schoeman-Kingdom, Coenraad de Buys. The First Transtaler, Pretoria 1938. Hofmeyr het hom betreklik gou na sy aankoms in Noord-Transvaal ook met die godsdienstige wel en wee van die blankes te Soutpansberg ingelaat. Hierdie aangeleentheid val nie binne die bestek van hierdie studie nie en is ook reeds behandel. Vgl. S. P. Engelbrecht, Geskiedenis van die Nederduitsch Hervormde Kerk van Afrika, Pretoria 1953, bls. 189-190, 235-237 asook S. P. Engelbrecht, Die Nederduitsch Hervormde Gemeente Pietersburg 1852-1952, Pretoria s.j., bls. 70-79. Wat G. D. Scholtz, Die Geskiedenis van die Nederduitse Hervormde of Gereformeerde Kerk van Suid-Afrika 1842-1885, Pretoria-Kaapstad 1956, bls. 224-227, 257-259 oor Hofmeyr en sy aanraking met die blankes in Soutpansberg beweer, kan alleen met versigtigheid hanteer word. 
'n suster van Ds. J. H. Neethling, in die huwelik getree het ${ }^{25}$.

Na sy bevestiging te Wynberg as sendeling deur prof. John Murray, het Hofmeyr met sy eggenote na Soutpansberg teruggekeer en daar werksaam gebly tot aan sy dood in 1905 .

$\mathrm{Na}$ sy dood het Eerw. E. Creux, 'n sendeling van die Paryse Evangeliese Sendinggenootskap, wat ook in die Soutpansbergdistrik werksaam was en Hofmeyr goed geken het, van hom geskryf ${ }^{26}$ :

Natuurlijk kon ik niet alles goed vinden, dat hij gezegd of gedaan heeft. Hij kon andere Christenen niet verstaan, die niet sijne opleiding en sijne ondervindingen hadden doorgemaakt. Het ontbrak hem aan kennis, maar sijne brandende liefde tot zijn Heer, zijne algeheele toegewijdheid aan zijn dienst, sijn totale onverschrokkenheid voor wat anderen zouden zeggen, gaf hem den waren Apostolischen geest, . . .

By 'n nadere beskouing van die struktuur van die teologie van Hofmeyr, is dit al dadelik duidelik dat ons hier met ' $n$ metodistiese georiënteerde teologie te make het. Daarby dat, vanweë die sterk emosionele inslag in die karakter van Hofmeyr, dit ' $n$ metodisme is waar die gevoel van die mens én sy religieuse ervaring 'n struktuur-bepalende faktor is $^{27}$. Dit moet egter hier gesê word dat Hofmeyr géén teologie in die ware sin van die woord besit nie. Die enigste wat Hofmeyr interesseer is die heilsleer, nié die teologie nie en daarom as van Hofmeyr se teologie gepraat word, is dit by wyse van spreke. Dit is miskien beter om alléen van sy heilsleer te praat, want hier het hy sy kenmerkende gedagtes ontplooi. Daarom is vir Hofmeyr die opwekking in metodisties-entoesiastiese gees dié groot doel van sy ampspraktyk ${ }^{28}$, dit waarop sy prediking gerig is ${ }^{29}$. Die opwekking wat deur Hofmeyr na aanleiding van die spraakgebruik van sy tyd, as 'n uitstorting van die Heilige Gees beskou is ${ }^{\mathbf{3 0}}$, het vir hom tot doel gehad die buitengewone openbaring van die krag van God in die bekering van die sorgelose sondaar en die lewendmaking van die geloof

\footnotetext{
$25 \mathrm{Vgl}$. A. Dreyer, a.w., bls. 52. Dreyer wys daarop dat Hofmeyr in 'n tyd toegelaat is toe vereis is dat die sendeling dieselfde akademiese $\mathrm{kwalifikasies}$ as dié van ' $\mathrm{n}$ kandidaat tot die Heilige Diens moes besit. Waarskynlik egter vanweë die dood van McKidd en die gebrek aan sendelinge (bls. 51) het die sendingkommissie van sy bevoegdheid om in besondere gevalle persone, wat nié die vereiste status besit nie, tot die amp van sendeling toe te laat, in die geval van Hofmeyr gebruik gemaak. Hofmeyr se voorafgaande akademiese prestasies laat twyfel ontstaan of hy inderdaad ooit aan die vereistes sou kon voldoen het. Vgl. ook S. Hofmeyr, a.u., blz. 43: Mijn verblijf in de Kolonie duurde van August 1866 tot Februarij 1867. Gedurende die zes maanden, moest ik mij gereedmaken voor mijn zendelingsexamen; ook nog in het huwelijk bevestigd worden.

2* M.N., a.w., blz. 145.

27 Vgl. o.a. S. Hofmeyr, a.w., blz. 29-30, 90, 110 en 192.

28 Vgl. M.N., a.w., blz. 124: In April 1891 gaf de Heer hem de groote vreugde te smaken, weer de teekenen van een opwekking te bespeuren. Zonder een opwekking kon hij niet leven.

20 Vgl. o.a. S. Hofmeyr, a.w., blz. 155, 171, 176. Hofmeyr het dit ook aanvaar dat 'n opwekking deur menslike toedoen tot stand kan kom. Vgl. S. Hofmeyr, a.w., blz. 157: Toen ik afscheid nam van de blanken, heb $\mathrm{ik}$ mij geregtigd gevoeld hen te verzekeren dat Gods Geest tot hen komen zou, indien zij volhardend en heilhegeerig daarom zou bidden.

30 Vgl. A. C. Barnard, a.w., bls. 139.
} 
van diegene wat reeds bekeer en gelowig is ${ }^{31}$. Maar dit moet begryp word dat Hofmeyr die opwekking beskou as 'n gebeurtenis wat mede deur die werksaamheid van die mens tot stand gebring kan word.

Oorspronklik kom hierdie gedagte van die opwekking voort as 'n verset téén 'n kerk wat verstar het of in 'n intellektualistiese ortodoksisme verstrik geraak het ${ }^{32}$.

Uit reaksie teen die formele en veruiterlikte kerk, word die hele nadruk gelê op die persoonlike beslissing, die persoonlike aanneming van Jesus Christus as daad van die mens. Teenoor die geïnstitueerde kerk, teenoor die ortodoksisme word die eteriese werklikheid van die siel geplaas, waarom dit, volgens die metodisme, na regte moet gaan ${ }^{33}$. By Hofmeyr is dit egter nié die dryfveer vir sy opwekkingsywer nie. Hofmeyr gebruik die opwekking as 'n middel om sy sendingwerk onder die Buyse en naturelle te bevorder en ook waarskynlik omdat die metode waardeur die mens die hemel kan bereik, vir die heidene die mees begrypbare vorm van godsdiens is. Want Hofmeyr vind by die naturelle, soos ook te verwagte was, geen aanknopingspunt vir sy verkondiging $n^{3 e^{34}}$. Tog het Hofmeyr wel 'n uitgangspunt vir sy strewe na 'n opwekking gevind omdat McKidd, sy voorganger, tog al iets bereik het $^{\mathbf{3 5}}$ :

hij (McKidd) had het volk op de statie aan het bidden gekregen. Er werd daar waarlijk niets gedaan zonder gebed. 's Ochtends vroeg in ' $t$ veld en na afloop van godsdienst en school, gingen groot en klein uit elkanderen in het veld, achter bosschen en miershoopen om te bidden.

In die jaar 1876 het dit Hofmeyr geluk om 'n opwekking op die sendingstasie tot stand te bring en daarmee het die massabekerings onder die naturelle en die Buyse en ook onder sommige blankes saamgegaan. Die opwekking wat hier gebeur het, het 'n aanwysbare orde en verloop gehad, ' $n$ vaste metode is gevolg wat by Hofmeyr as volg verloop:

(a) Deur middel van die prediking word die groot noodsaaklikheid van 'n aanwysbare persoonlike beslissing, 'n eie-persoonlike aanvaarding van Jesus Christus baie sterk beklemtoon ${ }^{36}$. Om die dwingende noodsaak te beklemtoon word die hoorder voor die uiterste grensmoontlikhede van dood, ewige verdoemenis of die wederkoms van Jesus geplaas maar dan op so 'n manier dat die onverwagte koms van hierdie sekerhede al die

${ }^{31}$ Dit is ook die algemeen-metodistiese opvatting van die begrip opwekking soos die stigtersfigure van die metodsme, Wesley en Whitfield, dit aanvaar het. Vgl. J. D. du Toit, Het Methodisme, Amsterdam-Pretoria 1903, blz. 37, 86, 96.

32 F. Boerwinkel, Kerk en Secte, Den Haag 1956², blz. 70 vg. sien die metodisme eerder as 'n korreksie op die tekort an liefde in die kerk. Vgl. ook J. D. du Toit, a.w., blz. 118-120, 139-140.

${ }^{33}$ H. R. Mackintosh, Types of Modern Theology, London 1954, p. 12. S. Hofmeyr, a.w., blz. 156, 240.

${ }^{34} \mathrm{~S}$. Hofmeyr, a.w., blz. 15 en 36 : Ik vond in geheel het districht Zoutpansbergen, geen enkel gedoopte of geloovige kaffer of Bastaard, geen voorstander eener gemeente, noch Evangelist, noch Sendeling. Zelfs op de statie was er slechts Br. McKidd die den Heer kende en voor Hem arbeidde.

35 S. Hofmeyr, a.w., blz. 36.

${ }^{36} \mathrm{~S}$. Hofmeyr, a.qv., blz. 268. 
nadruk kry ${ }^{37}$. Maar nie net dié uiterste moontlikhede word gebruik nie, maar enige tydsaanduiding is vir Hofmeyr in sy preke en gesprekke aanleiding genoeg om sy hoorder te wys op die groot noodsaak dat hy homself onmiddellik moet bekeer ${ }^{38}$.

(b) Hiermee gaan saam 'n uiteensetting van die diepte van die sondeval van die mens en sy absolute verdorwenheid voor die aangesig van God ${ }^{39}$. Hierdie uiteensetting wat 'n sterk emosionele inslag het, het telkemale by Hofmeyr se toehoorders aanleiding tot oormatige droefheid, gehuil en geskree gegee. Merkwaardig is dit terloops, dat by Hofmeyr se opwekkings hierdie gehuil gewoonlik by die kinders en lede van die vroulike geslag begin het ${ }^{40}$. Hierdie droefheid oor die sonde wat begaan is en die emosionele vrees vir die strawwe van die hel wat so plasties in die prediking geskilder is, het Hofmeyr as die duidelike teken van die teenwoordigheid van die Heilige Gees geïnterpreteer, die Gees wat werkende is in die harte van die gemeente ${ }^{41}$. Die emosionele uitbarstings in die kerkgebou het soms so erg geword, dat 'n normale erediens nié meer moontlik was $n^{42}{ }^{42}$. As gevolg van hierdie emosionele spanning het soms van die vreemdste dinge in die kerkgebou gebeur ${ }^{43}$ :

Doch het hartroerendste voor ons allen was de meid, die den 8sten. in flaauwte was gevallen. Ik zat op de grond toen zij bij ons kwam, en met een diepe onderaardsche stem begon sij uit te toepen: Waar is Maria Magdalena? Waar is Abraham? Waar is Johannes de Doper? Zij keerde naar ons en zeide: Neen, zij zijn niet hier, gelijken niet op u. $\mathrm{Zij}$ hebben vlerken en witte kleederen. Deze plaats is ook niet waar ik was (zij was wederom in eene flaauwte gevallen eer $z \mathrm{ij}$ bij ons kwam). Geduriglijk als zij bijkwam deed zij mij vragen-Eens vroeg zij: Wie is Hij, die hier nu geweest is? Daar is bloed aan zijne handen en voeten en zijde. Verscheidene malen zeide zij: Dienstknecht, de Heere roept u... Eene groote schare stond of zat dit alles aan te hooren. Wat ik gevoelde, kan ik niet beschrijven.

As die emosionele spanning in die gemeente eenmaal so hoog geloop het, is dit gehandhaaf deur deurlopende bidure, sang en openbare belydenisse van diegene wat dan reeds bekeer is. Dit is dan ook nie meer tot die

s. S. Hofmeyr, a.u', blz. 111, 140, 145 en 195: Ik had er over gesproken dat die deur een geopende is, doch binnen een halfuur kon die deur gesloten zijn, zelfs voor de onbekeerden, die nog leefden. Ik antwoordde hem dat er geen terror in een geopende deur is, maar wel voor hen, die er niet willen doorgaan.

$38 \mathrm{~S}$. Hofmeyr, a.w., blz. 169: ... doch ik wende mij naar de andere en zeide: ,en gij, zult gij $u$ ook niet nu an Hem geven daar Hij zoo nabij $u$ is? Zal de maan, die zoo aanstonds opkomt, $u$ nog eenmaal, als een onbekeerde beschijnen? Meer was niet noodig.

"S. Hofmeyr, a.w., blz. 249.

$10 \mathrm{~S}$. Hofmeyr, a.w., blz. 145 en veral 167.

1 S. Hofmeyr, a.w., blz. 146: Zuchten, tranen, ernst duidden de tegenwoordigheid van Gods Geest aan, blz. 161 : ... makkte het zoo duidelijk ik kon, dat die aandoening slechts Gods krachtdadig kloppen was aan het hart.

12 S. Hotmeyr, a.w., blz. 146: 's Namiddags sprak ik over Hosea VI: vs. 1: "Laat ons wederkeeren; Hij heeft geslagen; Hij zal genezen"-over de noodzakelijkheid om niet in ons verdriet te rusten. Het was mij slechts mogelijk door schreeuwen mij te laten hooren.

${ }^{43}$ S. Hofmeyr, a.w., blz. 182. 
kerkgebou beperk nie, maar oral, selfs in die veld, het die troossoekendes rondgedwaal ${ }^{44}$. Geen sakramentsbediening of prediking was dan meer moontlik nie ${ }^{45}$.

Dié emosionele spanning het dan ook verskillende van Hofmeyr se gemeentelede tot raserny gedryf en een het selfs waansinnig geword ${ }^{46}$.

Die oorsaak hiérvan kan gesoek word in die feit dat die onbekeerde onder geweldige geestelike druk geplaas word terwyl die eis gestel word dat die onbekeerde sélf vir Jesus moet kies, Hóm moet aanneem om so aan die ewige straf te ontkom. Dit is 'n kragdadige inwerking op die gevoel van die sondaar wat verower moet word en is daarop gemik om die selfvertroue van die onbekeerde só te skok sodat daar vanself 'n konfliksituasie in die geesteslewe van die onbekeerde geskep word ${ }^{47}$. Hierdie konflik is alléén oplosbaar as die onbekeerde Jesus anneem en ook die bekering ervaar ${ }^{48}$. Word die bekering nié ervaar nie, mag die arme onbekeerde weet dat hy vir ewig verlore is. Dit is dan ook met reg dat $\mathrm{Du}$ Toit hier van religieuse terrorisme praat ${ }^{49}$. Dat hiermee, deur die metodisme 'n verskynsel in die christelike godsdiens ingedra word wat nóg uit die Heilige Skrif nóg uit die vroeë christendom geken kan word, is wel duidelik vir diegene wat al enigsinds 'n studie van hierdie verskynsel gemaak het ${ }^{50}$.

(c) Op die intense berou, moet volgens Hofmeyr, dan dié gebeurtenis volg wat hy met die Bybelse term bekering aandui, want die hele emosionele hoogspanning is juis daarop toegespits om die bekering tot stand te bring. Gedurende die emosionele hoogspanning word die onbekende nou óf deur Hofmeyr óf deur 'n ander reeds bekeerde persoon, na die persoonlike beslissing gelei wat die innerlike konflik sal oplos ${ }^{51}$. Hierdie leiding vind by Hofmeyr nie noodwendig plaas deur middel van die prediking of die lees van die Heilige Skrif nie, maar hoofsaaklik deur

4 S. Hofmeyr, a.w., blz. 154: Ik heb die kinderen gezien en gehoord drie dagen en drie nachten zonder spijze, zonder slapen, niets doende dan bidden, danken en zingen ... Het is onmogelijk te slapen. Hier werd er gebeden, daar geweend, op eene andere plaats gezongen, zelfs in de Kafferkraal werd er geene spijse gekookt. Vgl. ook blz. 148,170 , en 177 .

45 Vgl. S. Hofmeyr, a.w., blz. 177: Ik moest in den namiddag weer kinderen doopen, en was verpligt dit maar in het gewoel te doen, want er was geens kans voor Zondagschool noch namiddag-dienst.

$46 \mathrm{Vgl}$. S. Hofmeyr, a.w., blz. 21, 116, 176, en 168: Men kon met het geloofsoog zien, hoe de Heilige Geest met den Satan streed om die ziel. Hij had het bitter en liep, na een paar woorden als een bezetene in het veld, geduriglijk met zijn handen slaande. Doch de Heilige Geest heeft de overwinning behaald, en ook hij zit aan de voeten des Heilands.

$4 \mathrm{~S}$. Hofmeyr, a.w., blz. 176: Ik was menigmaal de arme zielen zoo op de hielen, dat meer dan een, zoo als $z \mathrm{ij}$ nu met schaamte belijden, voor mij vluchtte.

${ }^{48} \mathrm{~S}$. Hofmeyr, a.w., blz. 177 asook 238. Vergelyk ook Hofmeyr se eie bekeringsverhaal.

4 "J. D. du Toit, a.w., blz. 142.

so A. von Harnach, Mission und Ausbreitung, S. 283: Schmerzlich vermissen wir es, dasz wir Biographien aus den drei ersten Jahrhunderten, die uns die Bekehrung oder das innere Wachstum und werden einer christlichen Personlichkeit schildern, nicht besitzen. Sie sind nicht untergegangen; denn sie nicht geschrieben werden. Vgl. ook R. A. Knox, Enthusiasm. A chapter in the history of religion, Oxford 1950, p. 4 sqq.

$51 \mathrm{~S}$. Hofmeyr, a.w., blz. 140: Ik zelf gevoelde mij zeer sterk aangedreven, zoo zelfs dat $\mathrm{ik}$ soms laat in den nacht nog uitging om te zien of er niet een was, dien ik kon aan. zetten om zich onmiddelijk aan den Heere Jesus over te geven. Vgl. ook blz. 146. 
voortdurende persoonlike gebed én deur die gesamentlike sing van opwekkende liedere ${ }^{52}$. Die hele aksent van die godsdiens word hierdeur in die terrein van die subjektiewe ervaring verskuif en hoewel daar nog 'n moment van die objektiewe gehandhaaf mag bly, is die patroon feitlik heeltemal subjektief-emosioneel ${ }^{53}$.

Die bekering vind dan plaas sodra die boetvaardige homself aan die Heer Jesus oorgegee het in die vertroue dat hom dan ook al sy sondes vergewe is. Dit moet egter ' $n$ tyd en ruimtelik bepaalbare oomblik wees want dit is immers die boetvaardige méns wat homself aan die Heer oorgegee het. Daarom word ook verwag dat die tans bekeerde 'n openlike verklaring van bekeerd-te-wees, moet kan afle $\hat{e}^{54}$.

Die bekering word deur Hofmeyr beskou as 'n finale daadwerklike breuk met die verlede van die bekeerde. Want nou, as 'n sondaar wie se sondes hom vergewe is ${ }^{55}$, wat nou vir die eerste keer werklik die Heer Jesus ken en Hom ook tot eiendom gemaak het ${ }^{56}$ en assodanig ook nou vir die eerste keer werklik die volle betekenis van die Heilige Skrif kan verstaan $^{57}$, kan die bekeerde vervolgens 'n lewe lei waarin die sonde steeds minder word ${ }^{58}$.

Die moment van die bekering val vir Hofmeyr dan verder ook saam met die wedergeboorte waardeur die bekeerde nou, mede deur sy eie toedoen, sy burgerreg in die Koninkryk van God.kry.

$\mathrm{Na}$ die emosioneel-gelaaide opwekking en die bekering en wedergeboorte wat daarop gevolg het, is die spel feitlik uit want nou bly daar nie so veel meer in die gewone lewe oor wat met die spanning van die bekeringstyd vergelyk kan word nie. Om nou egter kontinuiteit te bewerkstellig, voeg Hofmeyr twee elemente in sy teologiese gedagtestruktuur in om sodoende geestelike stagnasie te vermy.

Die eerste voorwaarde is dat die moontlikheid oopgelaat word dat die bekeerde weer kan terugval na die sondige toestand waarin hy voor sy daadkragtige bekering verkeer het. Daarom beklemtoon Hofmeyr ook die gedagte van die volharding na die bekering. Hoewel Hofmeyr dit 'n enkele maal stel dat die Heer diegene wat Hy verlos het, ook bewaar ${ }^{59}$, is dit tog vir Hofmeyr belangriker dat die bekeerling van sy kant voortdurend aktief sal bly om sodoende die terugval na die sonde self te $v^{v e r m y}{ }^{60}$. Die werksaamheid wat Hofmeyr aan die gelowiges voorskryf

52 S. Hofmeyr, a.w., blz. 169 en ook 147.

${ }^{5}$ S S. Hofmeyr, a.w., blz. 147.

s4 S. Hofmeyr, a.w., blz. 170 en 147: Ik ging naar de kinderen, vraagde hoe het met hen ging. Sommige zeiden: wij hebben den Heere Jesus gevonden, anderen, wij hebben onze harten aan den Heere Jesus gegeven. Ik zeide: Kinderen! als gij waarlijk uw hart aan den Heiland gegeven hebt, gaat dan uit, dankt Hem voor die genade, bidt Hem om $u$ vast te houden.

${ }^{5} \mathrm{~V}$ Vl. S. Hofmeyr, a.w., blz. 238, asook blz. 60 .

so $\mathrm{S}$. Hofmeyr, a.w., blz. 274. Kenmerkend in hierdie verband is dat Hofmeyr en sy bekeerlinge voortdurend verwys na "mijne Jezus", "Jezus in het hart" op so 'n manier dat daaronder verstaan word dat Jezus inderdaad die eie, verowerde "besit" van die bekeerling is. Vgl. hiervoor bv. blz. 155,163 e.a.

37 Vgl. bv. S. Hofmeyr, a.w., blz. 97.

${ }^{68} \mathrm{~S}$. Hofmeyr, a.w., blz. 270.

69 M.N. a.w., blz. 31 .

oo Vgl. bv. S. Hofmeyr, a.w., blz. 159. 
is nie net die sistematiese oefening in die geloof deur middel van die verenigings en konferensies en bidure wat vir dié doel daargestel word nie, maar ook die aktiewe deelname aan die bekering van die oorgeblewe sondaars ${ }^{61}$ :

Ik gevoel het een pligt om de geloovigen aan te sporen, toch niet tevreden te zijn, alléén naar de hemel te gaan, maar om te trachten anderen met zich mede te nemen; zij moesten trachten paarlen in hun kroonen te krijgen. Ik hoorde hoe eene zuster der gemeente, die sedert de laatste kerkdagen naar den hemel was gegaan, in de laatste opwekking (Mei 1877), toen hare zuster, aan wie zij veel had gearbeid, den Heiland op den kerkplaats vond, zoo angedaan werd, dat zij met hare handen klapte en uitriep: „Dank, Heere! nu heb ik ook een paarl in mijne kroon".

Dit is uit hierdie gedagte dat Hofmeyr se eie sterk ywer vir die sendingwerk voortgekom het ${ }^{62}$. Dit toon dat daar 'n sterk sunergistiese tendens in die teologiese struktuur van Hofmeyr aanwesig is. Kenmerkend is sy uitspraak $^{63}$ :-

Dit durf ik zeggen, is het eenige, dat mij in het Zendingwerk houdt.

Ware het niet om mijne Heiland te helpen op Zijnen troon te komen, dien Heiland, die mij zoo liefheeft, ik zou verslappen.

Daarom het Hofmeyr hom ook so met hart en siel in die sendingwerk gestort en geen moeite gespaar om die saak van die sending in die Kaapse Ned. Gereformeerde Kerk te bepleit nie ${ }^{64}$. Maar hierdie ywer om siele te red, die kenmerkende van Hofmeyr se werk, het ook een van die hoofoorsake van sy botsing met die Ned. Hervormde Kerk in NoordTransvaal geword ${ }^{65}$. En hierin is hy 'n tipiese navolger van Wesley, die stigter van die metodisme, van wie Du Toit sê ${ }^{68}$ :

Dit onkerkelijk streven, dat zielen poogt te redden met verwaarlozen van de Kerk, typeert zich in Wesley's levensmaxime: Kerk of geen kerk, zielen moeten worden gered.

Die tweede voorwaarde wat Hofmeyr stel om die kontinuiteit na die bekering te verseker, is die gedagte dat die sondelose bekeerde nou uit sy eie krag op die weg van die rolmaaktheid kan vorder op só .'n manier dat hy die absolute sekerheid van die heil reeds hier op aarde kan ervaar en ook tot absolute sondeloosheid hier op aarde kan op-

61 S. Hofmeyr, a.w., blz. 191.

B2 S. Hofmeyr, a.w., blz. 29-30. M.N., a.w., blz. 1-9.

63 S. Hofmeyr, a.w., blz. 135.

${ }^{64}$ M.N., a.w., blz. 30: Ik vrees, dat als onze Kerk niet begint te gevoelen, dat het zending. werk haar Hoofddoel moet zijn, dan gaat het zendingwerk voor onze Kerk verloren. Dit is dan ook volkome tereg dat Dreyer hom sien as een van die ywerigste sendelinge wat die Ned. Geref. Kerk in die vorige eeu na die Sendingveld gestuur het. A. Dreyer, a.w., bls. 52 .

${ }_{65} \mathrm{Vgl}$. S. Hofmeyr, a.w., blz. 28, 126, 133, 164, 169, en 249: En waren ook leden der Hervormde Kerk aldaar. Gelooft mij, ik heb moeite gedaan om hen te lokken door nartjes, azijn, zuurlimoenen, boeken, enz. enz., maar zij wilden mij niet vergeven dat ik een zendeling ben.

${ }^{66} \mathrm{~J}$. D. du Toit, a.w., blz. 118. Vgl. ook blz. 68-69; 139-140; S. Hofmeyr, a.w., blz. 25 ; M.N., a.w., bl. 36. 
klim $^{67}$. Verskillende male spreek Hofmeyr ook die gedagte uit dat hy ongetwyfeld salig sal word ${ }^{68}$.

Hiermee introduseer Hofmeyr 'n nuwe wettisisme en asketisme in sy teologie want dit is juis deur die naleef van vaste reëls en deur middel van die onthouding van al dié dinge wat as ,,sondes" beskryf word, dat die bekeerde die weg na die hemel volg. En verder vloei hieruit as negatiewe element voort, die geestelike hoogmoed waarna Eerw. Creux ook reeds verwys het ${ }^{69}$.

Want omdat Hofmeyr sélf die sekerheid van die heil meen te besit, daarom het hy homself ook bevoeg geag om te oordeel of andere al bekeer is of nie ${ }^{70}$. Hierdie heilsekerheid het egter netsoos Hofmeyr se teologie, sy oorsprong in die gemoed en die gevoel van die mens ${ }^{71}$ en is wel iets anders as die leer van die certitudo fidei wat ons by die reformatoriese vadere aantref ${ }^{2}$.

By die beoordeling van Hofmeyr se teologiese gedagtes moet steeds onthou word dat Hofmeyr self deur middel van 'n opwekking tot die bevindelike uitloper van die reformatoriese teologie gebring is. Geheel kind van sy tyd, is dit onwaarskynlik dat Hofmeyr óf deur studie óf deur ander invloede in kontak met die nugtere, suiwere reformatoriese teologie gekom het. Buitendien het sy emosionele geaardheid ook daartoe bygedra dat hy hom in die metodisme tuis gevoel het. Om Hofmeyr met een frase te tipeer val nie moeilik nie daar hy tot op groot hoogte as 'n verteenwoordiger van die evangeliese entoesiasme genoem kan word ${ }^{73}$, hoewel hy seker nie al die beslis-sektariese neigings van daardie rigting in sy eie teologiese gedagtewêteld opgeneem het nie.

In hoofsaak kan die besware teen Hofmeyr se metodisme in twee verdeel word. In die eerste plek gaan dit daarom dat by Hofmeyr die hele teologie én godsdiens tot ' $n$ subjektiewe beléwing geword het en dat die objektiewe heilsgebeure, tot in 'n groot mate weggedreineer word sodat die hele teologie verarm en vervlak word. Tiperend hiervan is die feit dat Hofmeyr 'n debat in 'n konferensie laat voer oor die gedagte:

om den dierbaren Heiland bij ons te houden, moeten wij Hem werk geven $^{74}$.

${ }^{67}$ S. Hofmeyr, a.w., blz. 249 waar Hofmeyr ds. A. Murray van Worcester en ds. Krige van Caledon as ",engele" tipeer.

${ }^{68} \mathrm{~S}$. Hofmeyr, a.w., blz. 248: Sedert dien aanval ben ik niet meer de zanger van vroeger; dit lokt menigmaal een traan uit mijn oog, doch ik denk aan het lied ter eere des Lams, dat daar boven zal gezongen worden, en o, kinderen! dan is het mij zoo zalig te weten dat ik ook tot dat zangkoor behoor.

oo Vgl. M.N., a.w., blz. 145. Vergelyk ook: S. Hofmeyr, a.w., blz. 192: Ik sprak over de woorden: "Wie is zij, die daat opklimt uit de woestijn en lieflijk leunt op haren liefste?" Het was mij onder het spreken, alsof de Heiland nu en dan zijne regterhand op mij plaatste en mij teederlijk aan zijn hart drukte...

70 Vergelyk o.a. S. Hofmeyr, a.w., blz. 94, 138, 150, 238.

${ }^{71} \mathrm{~S}$. Hofmeyr, a.w., blz. 250 .

72 J. D. du Toit, a.w., blz. 103, 164-165, 168.

${ }^{78}$ Hierdie tipering ontleen ek aan R. A. Knox, l.c, p. 130: The other (evangelical enthusiasm P.) more acutely conscious of man's fallen state, thinks always in terms of redemption; to know, somehow, that your sins are forgiven, that you are a new creature in God's sight, is all that matters.

i4 S. Hofmeyr, a.w., blz. 261 . 
Die duidelikste tree hierdie verarming aan die lig by Hofmeyr se leer van die Heilige Gees, hoewel dit in sy leer van God die Vader en sy leer van Jesus Christus óók aanwysbaar is ${ }^{75}$.

Sonder om nou die Bybels-reformatoriese leer van die Heilige Gees hier weer te gee, moet daar tog in kort op die afwykende tendense in Hofmeyr se gedagte hieroor, gewys word.

Die grondfout van Hofmeyr in sy leer van die Heilige Gees is dat hy die organiese verband tussen die Heilige Gees en Gods Woord losmaak deurdat hy die Heilige Gees sien as teenwoordig en werksaam in die gemeente buite die objektiewe gegewenhede van Woord en sakrament om. Die aanwysbare teenwoordigheid van die Heilige Gees konstateer Hofmeyr uit die emosionele aandoeninge wat sy gemeentelede beroer, en dit wil voorkom dat as dit nié gebeur nie, die Heilige Gees volgens Hofmeyr nie aanwesig is nie ${ }^{76}$. So beskryf Hofmeyr die begin van die opwekking in 1876 op sy sendingstasie as volg ${ }^{77}$ :

Ik geloof dat de Geest des Heeren eigenlijk zijn werk begonnen heeft in het Kinderbiduur. Er waren wel blazingen zoals: enkelen geduriglijk in tranen, anderen ernstiglijk biddende.

'n Ander keer in netso 'n sprekende voorbeeld, skryf Hofmeyr van sy blanke gemeente ${ }^{78}$ :

Wij verwachten echter Gods Geest ook op de kerkplaats, daar sedert eenige dagen sommige bijna niets meer konden doen dan rondgaan en ons zoeken, geduriglijk biddende, en bij het geringste woordje dat ik sprak, weenende.

Dat Hofmeyr in sy leer van die Heilige Gees voortdurend van 'n uitstorting van die Heilige Gees praat, is natuurlik 'n volkome verkeerde opvatting van die Pinkstergebeure in Jerusalem ${ }^{79}$. Dit gaan by Hofmeyr om 'n geestelike inspirasie, om 'n emosioneel-belaaide innerlike belewing van die mens. Die onkontroleerbare subjektiewe ervaring is vir Hofmeyr sowel die duidelik word van die werk van die Heilige Gees as die ervaring van die heil en dit is dan nié meer gebind aan die objektiewe Woord, Woordverkondiging of die sakramente nie ${ }^{80}$.

${ }^{75}$ Vanweë Hofmeyr se benadrukking van die opwekking is dit ook te verstaan dat die teologie en christologie by hom veel minder waarde as die pneumatologie het. Daarom word vir hierdie studie alléén oor laasgenoemde leer gehandel.

${ }^{76} \mathrm{Vgl}$. R. A. Knox, l.c., p. 2: For that is the real character of the enthusiast; he expects more evident results from the grace of God than we others. He sees what effects religion can have, does sometimes have, in transforming a man's whole life and outlook; these exceptional cases (so we are content to think them) are for him the average standard of religious achievement.

${ }^{77} \mathrm{~S}$. Hofmeyr, a.w., blz. 145.

$78 \mathrm{~S}$. Hofmeyr, a.w., blz. 161

70 Vgl. o.a. S. Hofmeyr, a.w., blz. 169: en ook Miss Tulleken klaagde over de doodschheid in hare school, en het was zwaar haar te zien vertrekken, eer dat Gods Geest op hare scholieren en de anderen kinderen uitgestort waren.

Jac. J. Muller, Sektes in Suid-Afrika, Kaapstad s.j., bls. 30: Omdat daar netsomin weer 'n Pinksterdag en Geestesuitstorting sal kom as wat Jesus weer gebore sal word. Die Godsdaad van die uitstorting van die Heilige Gees is enig in sy soort, en is, net soos die offer van Christus aan die kruis, eens en vir altyd geskied.

so Vergelyk hier O. Noordmans, Liturgie, Amsterdam 1939, blz. 88.

${ }^{81} \mathrm{~S}$. Hofmeyr, a.w., blz. 112: Wij willen weten of de Heilige Geest die zielekracht geeft, 
Natuurlik handhaaf Hofmeyr die Woordverkondiging en 'n enkele maal sal hy selfs die werking van die Heilige Gees aan die Woord koppel $^{81}$, maar gewoonlik is die Woordverkondiging vir Hofmeyr slegs ' $n$ onderdeel van die metodistiese metodologie ${ }^{82}$. As die opwekking van 1876 baanbreek dan kom die subjektiewe, dan kom die bekeerde mens met sy geestelike ervaring, volkome in die middelpunt te staan. Die Heilige Gees word steeds meer ,vervlak" en óók gesubordineer. In plaas daar'an dat die Heilige Gees 'n persoon is in die Drieëenheid wat God is, is die Heilige Gees by Hofmeyr slegs 'n ervaarbare krag. Daarom word Hofmeyr, as die objektiewe in sy teologie verlore gaan, sonder rem of kritiek deur die belewing van die opwekking meegesleep.

Zo wordt de Heilige Geest gemakkelijk als een gave gezien (wat Hij ook is), maar dan als een zaak, een pand, een bezit. Alles wat de Heilige Geest is en doet, zijn persoon en werk, schijnt geen ander bestand te hebben dan als geestelijk mensenleven. ... Wanneer wij er op die manier toe zouden komen om alleen in ",bevindelijken" zin, van de religieuse ervaring uit, over de Heilige Geest te spreken, dan zouden wij niet bijbels handelen ${ }^{83}$.

Daarom, as die bybels-reformatoriese leer van die Heilige Gees nagegaan word wat leer dat dié Gees wat mede van Christus uitgaan sódanig werk dat 'n Kerk gevorm word waar styl en orde aanwesig is ${ }^{84}$, dan kan met reg 'n vraagteken gestel word agter Hofmeyr se stelling dat die emosionele eredienste en ervarings van sy gemeentelede die werking van die Heilige Gees van God is. Soos Barnard dit stel ${ }^{85}$ :

Dit is dan ook onjuis om te veronderstel dat ware godsvrug alleen sou bestaan in die buitengewone, die opspraakwekkende, die emosioneelbelade-waarmee nie selde nie allerlei psigiese kragte soos suggestie, hipnose, opwinding en massagees vermeng is. Die gewone, diepdeurleefde vroomheid kan netso eg wees, en 'n godsdienstige weg wat ook objektiewe remminge het, netso suiwer, en die gewone middele soos die gewone prediking, die ampte, die gesonde rede, ens., kan netso onder die leiding van die Heilige Gees staan-dit is juis die vraag of dit nie by uitstek die Godgewilde weg is nie.

Dit is dus geen wonder dat diegene wat an die leer van die reformatoriese vadere bly vashou het, afwysend teenoor Hofmeyr en sy opwekkings gestaan het. Dit is ook nie verbasend as Hofmeyr daarvan beskuldig is dat hy dieselfde weg as die Groenewoudiste opgaan nie. ${ }^{86}$.

die het woord verstaanbaar en bewaarbaar makt; wij zijn overtuigd dat het woord in het hart alles regt zal maken.

82 Vgl. bv. S. Hofmeyr, a.w., blz. 45, 111, 145, 210, 269.

${ }^{83} \mathrm{O}$. Noordmans, Hetschepping, Amsterdam 1956², blz. 169

${ }^{84}$ O. Noordmans, a.w., blz. 170 . Vgl. ook Werner Krusche, Das Wirken des Heiligen Geistes nach Calvin. Göttingen 1957.

B5 A. C. Barnard, a.w., bls. 136. Vergelyk hier ook J. J. Muller, a.w., bls. 31 : Eindelik wys Paulus daarop (in I Kor. 12-14 P.) dat in die gemeente alles tot stigting moet geskied (vs. 26), en dat daarmee alle opgewondenheid, onordentlikheid, onpassendheid en buitensporigheid moet geban word, want dit stam nié uit die Gees van God nie, maar uit ons ou natuurlike wese, of nog erger miskien, uit die werkinge van die gees van die duisternis wat hom ook hier menigmaal voordoen as 'n engel van die lig.

s8 S. Hofmeyr, a.w., blz. 178. Oor die Groenewoudiste vergelyk A. Dreyer, a.w., bls. 47 
Hofmeyr het self die besware wat teen die opwekking en die subjektiwisme daarvan ingebring kan word, gedeeltelik onderken. Maar vanweë sy eié visie kon hy vir die gevare wat daarby dreig geen ander remedie voorstel nie as om maar te wag en te sien hoe eg die ervarings was $^{87}$.

$O$, neen! in tijden van opwekking hedriegt men zichzelven zeer ligt; en ook de leeraar wordt gemakkelijk bedrogen. De Satan neemt ook zijne kans waar, en meer dan een ziet zijne warmte en opgewektheid aan voor den Heiland. Later wanneer de warmte voorbij is, dan wordt het duidelijk dat sommigen Judassen en Demassen zijn.

Die objektiewe norm van die Heilige Skrif kom hier nie ter sprake nie, maar dit kan by Hofmeyr ook nie omdat die objektief-gegew'ene vir hom in waarde nié met die subjektiewe gelyk kan staan nie.

Daarom word die sakrament ook by Hofmeyr sterk gedepresieer want dit is immers die metode waarvolgens die mens salig word wat van belang is. Hoewel Hofmeyr die sakramente nog gereëld aan die gelowiges bedien, is die metodistiese tendens wat die sakrament as 'n blote survival beskou omdat dit in die metodologie nie pas nie, ook by hom aanwesig. In 1870 skryf Hofmeyr van een van sy bekeerlinge ${ }^{88}$ :

$\mathrm{Zij}$ heeft mij niet verzocht haar te doopen. Ik moedig haar niet aan. Ik verlang niet maar een groot getal gedoopten te hebben. Ik wensch den dierbaren en Volzaligen Jezus in de harten te zien, werkende, overtuigende, verlichtende, vertroostende, zittende op zijnen troon in het hart en den Satan en zijne werken onder Christus voeten.

Ook uit verskillende ander vermeldings blyk dat Hofmeyr die doop en die daarmee saamgaande verbondsgedagte nie hoogag nie. Vir Hofmeyr is dit nie die doop wat die inlywing in die gemeenskap van en met Jesus Christus bring nie, maar dit geskied deur die bekering en die wedergeboorte wat dan as grotendeels menslike prestasies gesien word. Dat Hofmeyr nie veel waarde aan die doop-sakrament heg nie word verder bevestig deur die feit dat hy in 1882 selfs twee buite-egtelike kinders in sy gemeente te Marabastad gedoop het. Die dan wel reeds getroude egpaar het self die kinders ten dope gehou. Maar nog vóór nog na die sakrament was daar 'n tugoefening tén die betrokke egpaar nie. Dit is verder ook nog 'n merkwaardige gebeurtenis omdat dit juis teen die wetties-asketiese opvattings van Hofmeyr behoort in te druis en dit laat die vraag ontstaan of Hofmeyr altyd sy beginsels en dié van die Kerk in wie se diens hy gestaan het, so konsekwent gehandhaaf het. Wat die doop betref, om weer terug te keer, wil dit voorkom asof dit vir Hofmeyr tot 'n naamgee-seremonie vervlak het ${ }^{90}$. By ander geleenthede blyk weer dat daar nog iets van die suiwer opvatting van die doop by Hofmeyr oorgebly het as hy na die doop as in die inlywing in die gemeente van Christus verwys ${ }^{90}$.

${ }^{87}$ Vergelyk S. Hofmeyr, a.w., bl.. 201.

${ }^{88} \mathrm{~S}$. Hofmeyr, a.w., blz. 111 .

89 S. Hofmeyr, a.tw., blz. 248 .

${ }^{\circ} \mathrm{S}$. Hofmeyr, a.w., blz. 225 . Vgl. ook blz. 50 waar sy subjektiwisme weer na vore kom. 
Ook wat die sakrament van die Awendmaal betref, kan daar van 'n depresiasie by Hofmeyr gepraat word. Hofmeyr sien dit dat die gemeenskap met Jesus Christus en met die ander gelowiges nié soseer in die gesamentlike viering van die Awendmaal beleef word nie, maar veel eerder in die subjektiewe ervaring van die geestelike opwekking. Juis die sterk indiwidualistiese tendens in Hofmey $\mathrm{r}$ se bekeringsteologie het as gevolg dat die enkeling van die gemeenskaplike en van die gemeente geïsoleer word ${ }^{91}$. Dit moet, byna noodwendig, 'n depresiasie van die Awendmaalsakrament as gevolg hê $\hat{~}^{92}$.

Aansluitend by Hofmeyr se opvatting van die Heilige Gees, kan daar bepaald onreformatoriese tendense in Hofmeyr se opvattings en beklemtoning van die bekering en wedergeboorte aangewys word. Sentraal in Hofmeyr se teologiese gedagtewêreld staan die verpligting dat die mens hom sal bekeer en wedergebore sal word. Dáárom, vanweë die groot waarde wat hy daaraan heg, is die bekering vir Hofmeyr 'n gebeurtenis wat duidelik ervaar en tydruimtelik bepaal moet kan word ${ }^{93}$, én een waarin die mens tot in 'n hoë mate meewerk om sy eie saligheid te verseker ${ }^{94}$. Hierdie hele bekeringsmetodiek wat Hofmeyr toepas, vloei voort uit die feit dat sy leer van die Heilige Gees nie reformatories is nie. Noordmans se uiteensetting gee die Bybels-reformatoriese opvatting as volg weer ${ }^{95}$.

De Heilige Geest is Herschepper. Er heeft scheiding plaats tussen de oude en de nieuwe mens, tussen boete en geloof (Zondag 33). Maar die twee sluiten niet bij elkaar aan; zij kunnen niet in elkaar onvergaan. De natuur gaat niet over in genade; berouw niet in geloof. De boete is een aflopend werk bij het afsterven van de oude mens; de gehoorzaamheid des geloofs een toenemende arbeid in de opstanding van de nieuwe mens.

Hierby kan daarop gewys word dat Hofmeyr uitgaan van die gedagte dat Gods genade, deur die inwerking van die Heilige Gees, nie alleen die sondige natuur van die mens oorwéldig nie, maar dat daardie natuur in

31 Vgl. hieroor o.a. J. D. du Toit, a.w., blz. 146-148. Sien S. Hofmeyr, a.u'., blz. 153.

92 'n Optrede van Hofmeyr waarteen geen direk-teologiese beswaar gemaak hoef te word nie, maar wat tog veel ergernis onder die blanke inwoners van Ncord-Transvaal veroorsaak het, is dat hy van tyd tot tyd Awendmaal bedien het waar blankes sowel as (bekeerde) naturelle aangesit het. S. Hofmeyr, a.w., bl $=221$.

Hier het Hofmeyr hom ook by die Kaapse gebruike aangesluit. In 1860 verklaar Dr. Wm. Robertson, een van die Kaapse Kerkleiers, op 'n konferensie te Wellington: "Het was hem (Robertson) dikwijls aangenaam geweest, in zijne eigene gemeente, met de eene hand het brood aan het Avondmaal aan een blanke, en in de andere aan een gekleurde toe te reiken".

Vgl. Verslag van de Werkzaamheden van de Christelijke Conferentie gehouden te W'orcester, op 18 en 19 April 1860, enz., Kaapstad 1860, blz. 33.

Vgl. ook Handelingen der Negende Vergadering van de Sijnode der Gereformeerde Kerk van Zuid-Afrika, Kaapstad 1858 waar besluit word: ,DeSijnode beschouwt het wenschelijk en schriftmatig, dat onze ledematen uit de Heidenen, in onze bestaande gemeenten opgenomen en ingelijfd worden overal waar zulks geschieden kan; ...'

-3 Vgl. bv. S. Hofmeyr, a.w., blz. 163: Een jonge man, de eerste mijner aannemelingen, ging dien achtermiddag naar zijn huis. Daar geen rust vindende kwam hij in den avond terug, en daar, bij het achteros-juk, viel hij neder en vond zijnen Heiland.

^ $\mathrm{Vgl}$. S. Hofmeyr, a.w., blz. 63: ... het zal getuigen tegen hen die geene moeite doen om den Heiland te bezitten.

Vergelyk ook: Die Heidelbergse Kategismus, Vraag en antwoord 59-65 en 89. 
die bekeringsproses totaal deur die vergiffenis van die sonde verander word, so dat selfs die erfsonde uitgewis word.

Daarby bring Hofmeyr se besondere benadrukking van die bekering 'n verskuiwing mee ten opsigte van die reformatoriese uitverkiesingsleer soos dit in die Leerreëls van Dordrecht 1618-1619 geformuleer is. Want Hofmeyr se uitverkiesingsleer is mede vanweë sy beklemtoning van die subjektiewe teenoor die objektiewe, in wese Arminiaans netsoos die uitverkiesingsleer van die metodisme ook Arminiaans is ${ }^{96}$.

Hofmeyr se hele regverdigingsleer kom kortliks op die volgende neer: Die mens ontrang 'n voorbereidende genade waardeur hy tot inkeer kom $^{97}$, waarna die roeping of opwekking volg deur middel van die biduur of soms ook die erediens ${ }^{98}$, dan volg die intense berou oor die sonde, die stryd om die bekering wat deur die mens gevoer word ${ }^{99}$, en dan volg as 'n resultaat die bekering en wedergeboorte ${ }^{100}$. As gevolg hiervan ontvang die mens die geloof in sy hart en terselfdertyd die regverdiging met die daarmee saamgaande vergiffenis van die sonde ${ }^{\mathbf{1 0 1}}$. Hierop volg dan die proses van die heiligmaking, waarin die mens weereens die hoofrol speel, en dit kan op die sondelose toestand van perfeksie uitloop. Hierdie heilsleer van Hofmeyr kan miskien die beste as antropologies-soteriologies gekarakteriseer word want dit gaan om die mens en sy vrye wil om hom te bekeer of nie. Dit beteken by Hofmeyr dat die mens se keuse hier uiteindelik die eindoordeel van God vervangwant, kies die mens nóu die regte weg dan wórd hy salig, kies die mens verkeerd, dan moét hy verlore gegaan ${ }^{102}$. Daarom kom die hele leerstuk van die uitverkiesing by Hofmeyr byna nie aan die orde nie-enkele male word die indruk wel geskep dat Hofmeyr van hierdie leerstuk bewus is. Maar dit het by hom geensinds dié inhoud of betekenis wat daaraan deur Dordtse leerreëls toegeken word nie.

Samehangend hiermee kan gekonstateer word dat die sentrale leerstuk van die reformatore nl. die regverdiging deur die geloof alleen, by Hofmeyr heeltemal op die agtergrond staan. As die kernagtige uiteensetting van die betekenis van die reformatoriese dogma van die regverdiging deur die geloof alleen soos deur Noordmans uitgedruk, met die

95 O. Noordmans, a.w., blz. 189.

98 J. D. du Toit, a.w., bl. 65 : Het Wesleyaansch Methodisme moet krachtens zijn wezen tegen de predestinatie zijn. De Wesleyaan treedt op met de pretentie heel de wereld te zullen bekeeren, en dit kan hij alleen doordien hij zich baseert op de leer der algemeene e'erzoening en breed roemt van een Christus pro omnibus.

S. Hofmeyr, a.w., blz. 176: Ik beschuldigde mijzelven en de geloovigen als oorzaken dat er nog zoo vele onbekeerden onder ons waren. Onze leus moet zijn: geen klaauw moet achterblijven.

7 Vgl. M.N., a.w., blz. 5: Ik werd vroom en werd gerespecteerd, doch ik gevoelde diep, dat $\mathrm{ik}$ met mijne vroomheid verloren ging, want ik was „onwedergeboren".

8 S. Hofmeyr, a.w., blz. 147.

90 S. Hofmeyr, a.w., blz. 161 : ... maakte het zoo duidelijk ik kon, dat de aandoening slechts Gods krachtdadige klopping was aan het hart en dat zij zich aan den Heiland moesten overgeven, ...

Vgl. ook J. D. du Toit, a.w., blz. 159-160.

100 Vgl. o.a. S. Hofmeyr, a.w., blz. 169, 177.

101 Vgl. o.a. S. Hofmeyr, a.u., blz. 97.

102 Vgl. hier Joh. 15:16: Julle het My nie uitverkies nie, maar Ek het julle uitverkies. 
heilsleer van Hofmeyr vergelyk word, dan blyk die groot afstand wat daar tussen die reformatoriese teologie en Hofmeyr se teologiese gedagtes bestaan, byna onmiddellik. Nordmans stel dit as volg ${ }^{103}$ :

De voornaamste reden waarom de rechtvaardiging door het geloof in het centrum van de prediking staat is deze, dat daarin het duidelijkst uitkomt, wat de eigenlijke drijfveer der evangelie verkondiging is. Het is een boodschap van godswege. En daaruit blijkt, dat alleen een oordeel Gods, ... een scheppingswoord Gods, waardoor alle dingen nieuw worden, ons kan redden. De roeping kan worden voorgesteld als een voorwaardelijken aanbod, de wedergeboorte als een hypothese, de bekering als een tijdelijk proces, de heiliging als een menselijk streven. Maar aan de rechtvaardiging kan niet worden toe of afgedaan. Men moet haar verwerpen of in haar geheel laten staan.

By Hofmeyr gaan dit daarenteen om die algemene versoening wat daarin bestaan dat die mens in die moment van sy bekering en wedergeboorte, sondeloos word en sodoende in beginsel reeds die heil in sy besit kry. Maar dan is die regverdiging nié die toereken van die verdienste van Jesus Christus wat aan die mens gegee word as genadegawe op grond van die geloof wat deur die Heilige Gees in sy hart ingeplant is nie, maar dit is 'n toerekening van die gevolge van die verdienste van Christus op grond van die prestasie wat die mens gelewer het. Die gevolge van die verdienste van Christus kom die mens ten goede en dit bestaan daarin dat sy sondes uit sy verlede hom vergewe word. Wat die toekoms betref is die besit van die wedergeboorte in beginsel die waarborg daarvoor dat die mens nie meer sal sondig nie. Daarom kan gesê word dat insover die regverdiging as leerstuk-by-implikasie by Hofmeyr bestaan, dit nie van juridiese nie maar alleen van eties-subjektiewe belang is. In Hofmeyr se heilsleer, in sy visie van die bekering en wedergeboorte, en by implikasie dan van die regverdiging, gaan dit in werklikheid nié om die nuwe begin van 'n lewe as 'n kind van God nie, 'n lewe wat deur God self begin is nie, maar dit gaan om 'n soort donum superadditum, in roomse sin, waarmee God die strewe van die mens bekroon. Heeltemal vry is God dan ook nie in hierdie verandering van die mens nie.

Soms wil dit voorkom asof Hofmeyr sy synergistiese heilsleer wil modifiseer insover dat hy dan tog weer wil anvaar dat dit God is wat die verandering in die mens se hart bewerk ${ }^{104}$ dat die heil van God tóg 'n objektiewe gegewenheid en nié 'n subjektiewe moontlikheid is nie ${ }^{105}$, maar hierdie gedagtes is nié die hoofmoment van Hofmeyr se heilsleer nie.

Miskien moet hiervoor die fout gesoek word in Hofmeyr se onreformatoriese sondeleer. Sonde is nié meer vir Hofmeyr ' $n$ besmetting

${ }^{103}$ O. Noordmans, a.w., blz. 180. Vgl. ook blz. 182 en 185 . Vgl. G. C. van Niftrik, Kleine Dogmatiek, Nijkerk 19534, blz. 347 en veral blz. 351 . . daarom is ret niets anders als geestdrijverij, wanneer ... de wedergeboorte door de Heilige Geest als een zeer aparte ervaring-, als de ervaring en beleving hoog boven het gelorf en de rechtvaardiging wordt gesteld.

$104 \mathrm{~S}$. Hofmeyr, a.w., blz. 207: Ik zeide hem dat ik meende, dat de Heere daardoor toont dat het (die bekering) niet ons werk is ...

105 M.N., a.w., blz. 33. 
waaraan die mens ly nie, dit is nie meer die opstand teenoor God nie, maar dit is slegs ' $n$ korrigeerbare foutiewe tendens wat in die mens ingeskape is wat hy weer met 'n sekere inspanning kan oorwin. En hierin is Hofmeyr dan Pelagiaans.

Ten slotte mag daar nog op die sterk synergistiese tendens gewys word wat Hofmeyr in die christelike gebedspraktyk introduseer. Daarmee hang 'n sterk subjektiwisering van die gebed ook saam. Hofmeyr beskou die biduur as van veel meer belang as die gewone erediens waarin die verkondiging van die $\mathrm{W}^{\prime}$ oord sentraal staan ${ }^{106}$. Daarby kom dat Hofmeyr die voorbidding besonder noodsaaklik ag want die uitbreiding van die Evangelie is nié moontlik en kan ook nie voortgaan as die mens daarvoor nie ook iets doen nie ${ }^{107}$. So word die gebed by Hofmeyr verplaas van die locus van die dankbaarheid waar dit deur die Heidelbergse Kategismus gestel word, na dié van die soteriologie ${ }^{108}$.

'n Verdere merkwaardige moment in Hofmeyr se gedagtewêreld is sy opvatting van die begrip genade. Dit vervlak by Hofmeyr volkome, so dat hy genade bloot sien as 'n energie-inspuiting wat van bo kom. Telkemale word dit by Hofmeyr aangetref dat hy vir die voltooiing van 'n bepaalde taak van die Heer ,dubbele" genade vereis ${ }^{109}$. Hiermee hang saam dat Hofmeyr in selfs die kleinste dingetjies wat gebeur of direkte bemoeienisse van God sien of daarvoor vra sodat feitlik niks in Hofmeyr se lewe „normaal" verloop nie ${ }^{110}$. Die vraag kan dan ook gestel word of ons hier nie tot by die vlak van die magie gedaal het nie.

Hierdie opvattings vind hulle oorsprong waarskynlik in Hofmeyr se emosionele karakter wat nooit met die normale tevrede kan wees nie maar wat sug na die abnormale om juis daarin die tekort in sy geloof, wat vanweë sy subjektiwisme ontstaan, aan te vul.

Met hierdie aantekeninge by Hofmeyr se gedagtes wil volstaan word. Dit moet egter weer gesê word dat Hofmeyr geen teoloog is nie. Hofmeyr is alleen ' $n$ opwekkingsprediker. Daarom het Hofmeyr vir die SuidAfrikaanse dogmengeskiedenis weinig of geen betekenis nie-maar hierdie studie wil aantoon, waarom Hofmeyr se optrede, prediking en praktyke soveel verset in Noord-Transvaal uitgelok het by dié mense wat die Byhelse leer van die reformatoriese vadere nie wou versaak nie.

Pretoria

A. D. Pont.

Maart 1958.

\footnotetext{
$106 \mathrm{~S}$. Hefmeyr, a.u., blz. 250: Ik beschouw biduren, als de pols eener gemeente. Men kan $\mathrm{er}$ aan zien, wat de geestelijke toestand eener gemeente is.

107 S. Hofmeyr, a.w., blz. 160.

108 S. Hofmeyr, a.w., blz. 137 en ook 221. Die vraag na die waarde van die biduur assodnig, word hier met rus gelaat.

109 Vgl. S. Hofmeyr, a.w., blz. 37, 97.

110 Vgl. o.a. S. Hofmevr, a.w., 212, 231, 233. Oor die begrip genade vgl. o.a. O. Noordmans a.w., blz. 177 asook Ralf Luther, Neutestamentliches Worterbuch-Eine Einführung in Sprache und Sinn des urchristlichen Schriftums, Berlin o.J., S. 73, 74.
} 